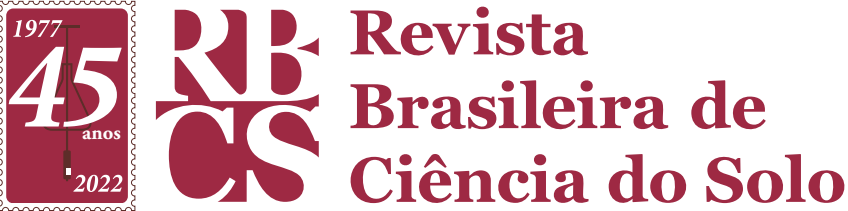

Division - Soil Use and Management | Commission - Soil Fertility and Plant Nutrition

\title{
Nitrogen release from pelletized poultry fertilizer in two soils: influence of soil moisture and microbial biomass
}

\author{
Elga Monaci ${ }^{(1)}$ (iD, Carlo Angeletti ${ }^{(2)}$ iD, Cristiano Casucci ${ }^{(1)}$ iD and Costantino \\ Vischetti $^{(1)^{*}}$ \\ (1) Polytechnic University of Marche, Department of Agricultural, Food and Environmental Sciences, Ancona, \\ Italy. \\ (2) Polytechnic University of Marche, Department of Clinical Sciences, Section of Biochemistry, Ancona, Italy.
}

* Corresponding author:
E-mail: c.vischetti@univpm.it

Received: September 03, 2021

Approved: November 05, 2021

How to cite: Monaci E, Angeletti C, Casucci C, Vischetti C.

Nitrogen release from pelletized poultry fertilizer in two soils: influence of soil moisture and microbial biomass. Rev Bras Cienc Solo. 2022;46:e0210101.

https://doi.org/10.36783/18069657rbcs2021010

Editors: José Miguel Reichert (i) and Leandro Souza da Silva (D.

Copyright: This is an open-access article distributed under the terms of the Creative Commons Attribution License, which permits unrestricted use, distribution, and reproduction in any medium, provided that the original author and source are credited.
ABSTRACT: Nitrogen release from organic amendments, e.g., from organic agriculture, is a key process to raise soil fertility to sustain crop production in low environmental impact agroecosystems. This study aimed to investigate nitrogen release from a pelletized organic amendment containing poultry litter, guano and pot ale applied to soil from a field under two different management systems: an alfalfa-based crop rotation, enriched with $\mathrm{N}$ by the legume, under low-intensity tillage and a cereal-sunflower crop rotation under high-intensity tillage. Both sample types were evaluated under different temperature and soil moisture conditions (optimal and variable). The influence of the released amount of $\mathrm{N}^{-\mathrm{NO}_{3}}$ on soil microbial biomass, soil basal respiration as well as on $\beta$-glucosidase, alkaline phosphatase and o-diphenoloxidase were investigated. The soil fertility level under low-intensity was higher than under high-intensity tillage. Consequently, compared to the control, microbial biomass growth in pellet-treated samples was intensified, both under optimal and variable conditions. Nevertheless, at the end of the experiment under variable conditions, microbial biomass decreased down to the level of the control. Soil moisture was identified as the limiting factor for basal respiration in low-tillage soil, while in the intensively tilled soil, low fertility was limiting, and respiration increased in response to pellet application, supplying $C$ for microbial biomass. During the experimental period, the investigated enzyme activities were somewhat intensified by pellet application, contributing slightly to improve soil biochemical fertility. More $\mathrm{N}-\mathrm{NO}_{3}$ was released from soil under low than high-intensity tillage; however after 90-days, the pellet was not completely mineralized, and even at optimal soil moisture content, nitrate release was only partial. This indicated that pelletizing, though useful for practical reasons such as handling, storage and field distribution, can reduce the fertilization efficiency of organic amendments.

Keywords: pelletized organic fertilizers, soil basal respiration, soil enzymes, available nitrogen. 


\section{INTRODUCTION}

Organic waste should no longer be considered a waste product, but rather a resource that farmers can use to improve the fertility of arable soils. Organic manures contain several important nutrients and organic matter, which, when applied to the soil, may increase nutrient availability, humic substances content and water-holding capacity, and improve soil structure. Several organic amendments for arable soils are currently available, which are by-products from farms, agro-food companies or municipalities. They can be applied raw or somehow processed, e.g., by anaerobic digestion, composting or drying/pelletizing.

Soil fertilizers can be distinguished from soil conditioners according to the main effects on soil properties. Fertilizers are a source of relatively readily available nutrients and have a direct, short-term effect on plant growth. Soil conditioners on the other hand affect plant growth indirectly by improving nutrient bioavailability and/or soil physical and biological properties. Animal manures are organic amendments with value as soil fertilizers as well as conditioners. In general, raw manures are good sources of N, P and $\mathrm{K}$, as well as of organic matter. Composting changes the manure quality; in fact, nutrient availability will be lower after composting (Paul and Clark, 1996), but the composted manure is biologically much more stable and odor-, weed- and pathogen-free (Sims and Wolf, 1994; Lopez-Mosquera et al., 2008).

Nutrients in commercial fertilizers are highly soluble and nutrient availability to plants is quite predictable. On the other hand, organic amendments vary widely in how quickly nutrients become available to crops. Since this mineralization is a biochemical process mostly mediated by the microbial biomass level and activity, the nature of the source is decisive, be it manure, compost or green residues. As a result, the capability of organic amendments to sustain crop production on arable soils may markedly change with soil physical-chemical conditions and biochemical properties.

Currently, organic residues are additionally treated during pelletizing. This is a physical process that consists in drying the fresh litter to $8-10 \%$ of the initial moisture (in a tunnel dryer at $250^{\circ} \mathrm{C}$ ). The dried material is then ground in a hammer mill, filtered and eventually compacted to pellet (mean diameter and length 5 and 12-14 mm, respectively) in a granulator press. Pelletizing organic residues is a widely used approach to reduce the volume of the fresh material and facilitate handling, transport, storage and field application (McMullen et al., 2008).

Composting and pelletizing of animal manures, also in mixtures with other organic residues, seems promising as a possibility of producing organic amendments that release nutrients, while the pathogens and antibiotic residues contained in fresh litter are minimized. In addition, compared to compost, pellet application may further delay nutrient release, thus reducing adverse environmental effects such as nitrogen leaching and run-off from farmland. However, due to the longer durability, pelletized organic manures may be less accessible to soil microorganisms, nutrient release to crops may decrease and in the worst case, crop yields may be lower in organically managed soils. Per definition, the sustainability of crop production in the low-input-agroecosystems of organic farming may only be improved by organic amendment application, while inorganic fertilizers are not allowed.

Especially in these agroecosystems, the application of organic amendments needs to be well-timed to ensure nutrient availability before the highest crop demand. The amendments should be mineralized near the time of maximum plant uptake to warrant satisfactory yields. It must also be taken into account that complementary in-season applications are difficult and organic amendment completion would therefore hardly be helpful in the case of nutrient deficiency. In organic farming, if the nutrients are unavailable for early plant growth, yields may be compromised. In comparison to 
fresh residues or compost, the microorganism mineralization of pelletized organic amendments may be less prone to an efficiency loss to meet crops needs.

Many studies described the effects of temperature and soil moisture on nitrogen released from organic amendments, mentioning an increase in nitrogen release after a rise in soil moisture. Increases in $\mathrm{N}$ release from chicken manure of 12 and $21 \%$ were reported by Agehara and Warncke (2005) in response to a soil moisture variation from 50 to $60 \%$ and $90 \%$ water-holding capacity (WHC), respectively. A number of studies have analyzed practical aspects and environmental benefits of pelletized organic amendments (Loyon, 2017; Drozdz et al., 2020), although little is known about how pelletizing may affect nutrient release efficiency in relation to crop uptake and yields.

This paper investigated the efficiency of a pelletized organic amendment containing poultry litter, guano and pot ale by analyzing soil from a field under two different management systems: (i) an alfalfa-based crop rotation enriched with $\mathrm{N}$ by the legume and under low-intensity tillage (L); and (ii) a cereal-sunflower rotation under high-intensity tillage $(\mathrm{H})$.

\section{MATERIALS AND METHODS}

In a 90-day laboratory experiment, the pellet efficiency in soil samples from the two treatments was tested for $\mathrm{N}-\mathrm{NO}_{3}$ release and variation in microbial biomass carbon (MB-C), soil basal respiration (SBR), $\beta$-glucosidase ( $\beta$-GLU), ortho-diphenol oxidase (o-DPO) and alkaline phosphatase (AmP), under different temperature and soil moisture conditions.

\section{Soil sampling and analyses}

The soil used in the experiment was classified as Vertic Eutrudept (Soil Survey Staff, 2014). Samples were collected from the surface layer (0.00-0.30 m) of soil under organic management for the last 13 years, at the Experimental Farm Pasquale Rosati (Gallignano, $43^{\circ} 57^{\prime} \mathrm{N}, 13^{\circ} 43^{\prime} \mathrm{E}, 100 \mathrm{~m}$ a.s.I.) of Marche Polytechnic University, Ancona, Italy. Two plots corresponding to two different cropping systems were sampled: alfalfa/cereals under low and sunflower/cereals under high-intensity tillage. A non-systemic pattern (Paetz and Wilke, 2005) was used to collect 24 soil samples per plot. The main physico-chemical properties of the soil samples from the two management systems (henceforth called "treated" soil) and the applied organic amendment are listed in table 1. Additional data on soil and site were compiled by Monaci et al. (2017).

Pellets consisting of pot-ale, guano and chicken droppings were added to soil samples to ensure a fertilizer rate of $1500 \mathrm{~kg} \mathrm{ha}^{-1}$. Plastic boxes $(0.05 \mathrm{~m}$ diameter $\times 0.07 \mathrm{~m}$ height) were filled with $50 \mathrm{~g}$ soil of each management, alfalfa $(\mathrm{L})$ and cereal $(\mathrm{H})$, with pellet. The pellet contained $35 \%$ organic C, $5 \%$ total $\mathrm{N}\left(4 \%\right.$ organic $\mathrm{N}$ ) and $5 \% \mathrm{P}_{2} \mathrm{O}_{5}$ and the chemical properties met the requirements of organic farming as established by the Italian

Table 1. Physico-chemical properties of the investigated soil under two management systems and pelletized organic amendment

\begin{tabular}{lccc}
\hline Property & Low tillage intensity & High tillage intensity & Pellet (poultry litter + pot ale) \\
\hline Soil texture & Clay-loam & Clay-loam & 7.0 \\
$\mathrm{pH}\left(\mathrm{H}_{2} \mathrm{O}\right)$ & 7.95 & 8.0 & 0.75 \\
Bulk density $\left(\mathrm{Mg} \mathrm{m}^{-3}\right)$ & 1.40 & 1.48 & 60.3 \\
$\mathrm{SOM}(\%)$ & 2.50 & 1.0 & 35.0 \\
$\mathrm{C}_{\text {org }}(\%)$ & 1.44 & 0.60 & 5.0 \\
$\mathrm{~N}_{\text {tot }}(\%)$ & 0.23 & 0.11 & 4.0 \\
$\mathrm{~N}_{\text {org }}(\%)$ & - & - & 5.0 \\
$\mathrm{P}_{2} \mathrm{O}_{5}(\%)$ & 0.0036 & 0.0048 & 7.0 \\
Moisture content $(\%)$ & 10.0 & 10.0 & \\
\hline
\end{tabular}


Ministry of Agriculture (Mipaaf, 1995). Samples were incubated under two regimes of soil moisture and temperature: optimal $(0)\left(60 \% \mathrm{WHC} ; 22^{\circ} \mathrm{C}\right.$ ) and variable $(\mathrm{V})$ (soil moisture and temperatures to simulate, at a small scale, real climatic conditions as normal in the period of field application of organic amendments). The climatic conditions of a 4-month period (February-April) were considered, and soil moisture and temperature were weekly adjusted based on the regional weather bulletin data of Marche, Italy: $15 \%$ soil moisture and $12{ }^{\circ} \mathrm{C}$ in the first two weeks, $25 \%$ soil moisture and $15{ }^{\circ} \mathrm{C}$ in the next four weeks, $20 \%$ soil moisture and $15{ }^{\circ} \mathrm{C}$ in the next four weeks and $15 \%$ soil moisture and $18{ }^{\circ} \mathrm{C}$ in the last two weeks. Soil samples of alfalfa and cereal management without pellet were also incubated as controls, under the above conditions. The experiment was performed in duplicate with a total of 144 samples from $72 \mathrm{~L}$ (18 samples with pellet, L-O, and 18 control samples, L-OC, under optimal conditions; 18 samples with pellet, L-V, and 18 control samples, L-VC, under variable conditions) and $72 \mathrm{H}$ (18 samples with pellet, $\mathrm{H}-\mathrm{O}$, and 18 control samples, $\mathrm{H}-\mathrm{OC}$, under optimal conditions; 18 samples with pellet, $\mathrm{H}-\mathrm{V}$, and 18 control samples, $\mathrm{H}-\mathrm{VC}$, under variable conditions).

Three sub-samples were collected from each plot and analyzed for microbial biomass-C (MB-C), enzymatic activities and available $\mathrm{N}^{-N_{3}}$, after $0,7,15,30,60$ and 90 days of incubation. Microbial biomass- $C$ was determined by the fumigation and extraction method (Vance et al., 1987). Alkaline phosphatases (AMP) and $\beta$-glucosidase ( $\beta$-GLU) activities were assayed according to the methods of Eivazi and Tabatabai (1977) and Eivazi and Tabatabai (1988), respectively. O-diphenoloxidase (o-DPO) activity was assayed as proposed by Perucci et al. (2000). Available $\mathrm{N}^{-\mathrm{NO}_{3}}$ was determined by extraction from $10 \mathrm{~g}$ soil with $0.01 \mathrm{~mol} \mathrm{~L}^{-1} \mathrm{KCl}$ and quantified by an ion chromatography system (Dionex ICS1000) equipped with IonPac AG9-HC $(4 \times 50 \mathrm{~mm})$ guard and IonPac AS9HC analytical $(4 \times 250 \mathrm{~mm})$ column.

Soil Basal Respiration (SBR) was measured in triplicate in a parallel trial with 36 soil samples ( 2 soils $\times 2$ treatments $\times 3$ moisture regimes $\times 3$ replicates) of $25 \mathrm{~g}$, each incubated at three soil moisture regimes $(20,40$ and $60 \% \mathrm{WHC})$, at $22{ }^{\circ} \mathrm{C}$. The samples, named according to the soil type, treatment and soil moisture regime (L-60, L-60C, L-40, L-40C, L-20, L-20C, H-60, H-60C, H-40, H-40C, H-20, H-20C) were incubated for 54 days, and basal respiration was controlled along $1,4,7,10,15,21,27,40$ and 54 days after the beginning of the experiment. Soil basal respiration (SBR) was determined by trapping $\mathrm{CO}_{2}$ (30 g dry soil) in $\mathrm{NaOH} 0.5 \mathrm{~mol} \mathrm{~L}^{-1}$ within sealed incubation vessels for a 56 day-period at three different soil moisture conditions (20, 40 and $60 \% \mathrm{WHC})$. The $\mathrm{CO}_{2}$ concentration was determined by adding $\mathrm{BaCl}_{2}(20 \% \mathrm{w} / \mathrm{v}$ aqueous solution) and subsequent titration with $\mathrm{HCl} 0.1 \mathrm{~mol} \mathrm{~L}^{-1}$ (Dumontet and Mathur, 1989).

\section{Statistical analysis}

Soil chemical and biochemical properties were analyzed by two-way ANOVA and Tukey's HSD tests $(p<0.05)$. All statistical analyses were performed using JMP.10 (SAS Institute Inc., USA).

\section{RESULTS}

As the release of nutrients from pelletized organic amendments is a process strictly mediated by the level and activity of soil microbial biomass, it is important to study its response to pellet application at different soil moisture levels. Results of MB-C content in untreated (control) and treated soils under different soil moisture and temperature conditions are presented in figure 1.

The soil under low-intensity tillage $(\mathrm{L})$ initially had a higher MB-C content than intensively tilled $(\mathrm{H})$ soil (mean of $\sim 300$ versus $120 \mathrm{mg} \mathrm{kg}^{-1}$ ). This was expected because of the initial higher fertility level of $L$ soil (Table 1 ). The amount of MB-C was significantly higher 
L - Optimal conditions

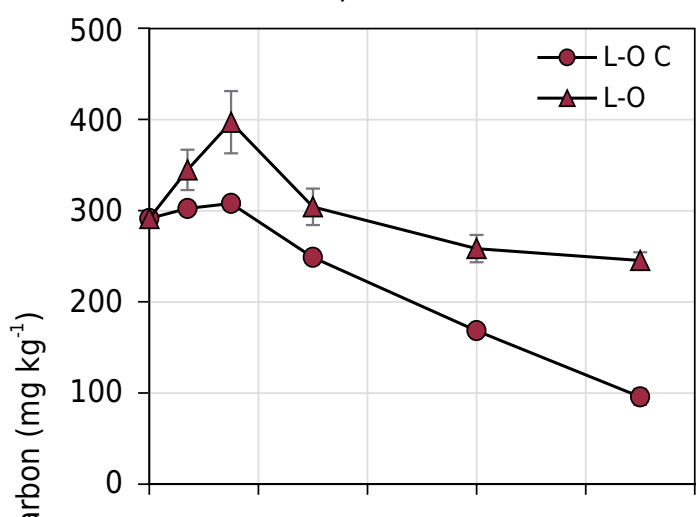

$\mathrm{L}$ - Variable conditions

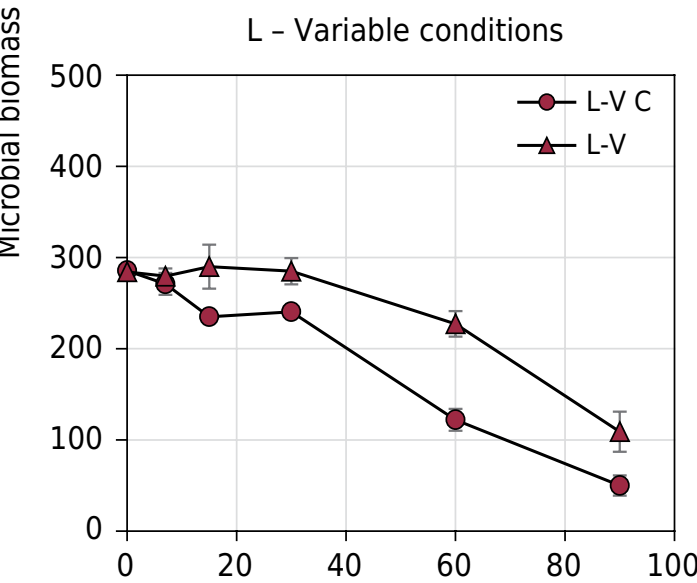

$\mathrm{H}$ - Optimal conditions

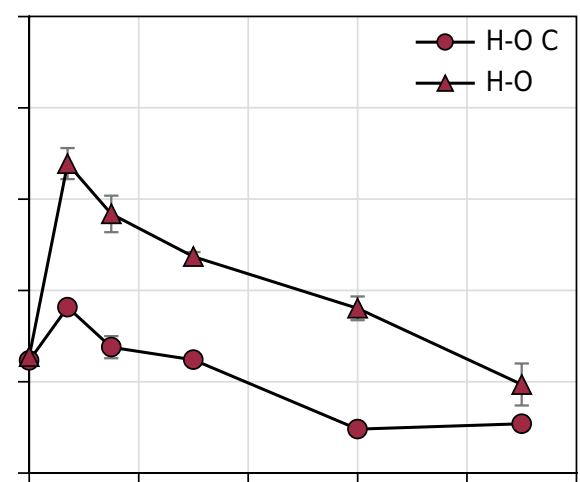

H - Variable conditions

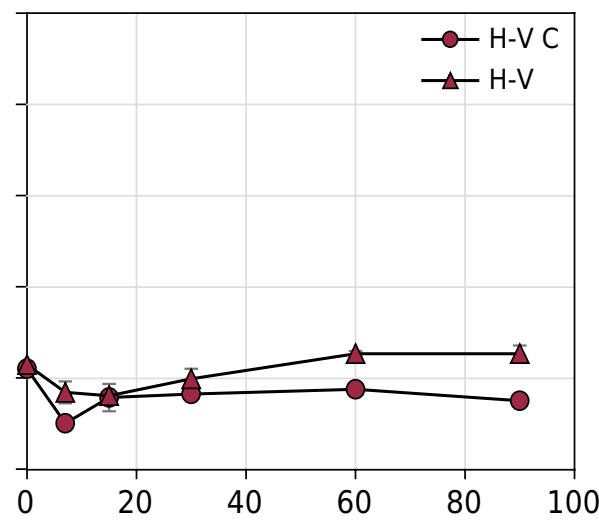

Days after treatment

Figure 1. (MB-C) content in un-treated $(C)$ and treated soils under low $(\mathrm{L})$ and high $(\mathrm{H})$ tillage intensity, at optimal $(\mathrm{O})$ and variable $(\mathrm{V})$ temperature and soil moisture conditions (mean of four replicates \pm standard deviation).

in treated soil than in control samples at all sampling times, as of day 7. In general, during the incubation period, pellet addition induced a mean MB-C increase of 49.8 and $55.0 \%$ in L-V and L-O, respectively, and of 36.4 and $124.4 \%$ in $\mathrm{H}-\mathrm{V}$ and $\mathrm{H}-\mathrm{O}$, respectively, in comparison to the respective controls.

Under optimal conditions, MB-C increased noticeably in both L-O and $\mathrm{H}-\mathrm{O}$ soils seven days after treatment, when $\mathrm{H}-\mathrm{O}$ reached the same level as $\mathrm{L}-\mathrm{O}$ soil. On the other hand, while in $\mathrm{L}-\mathrm{O}$, the MB-C level remained high until the end of the experiment, in $\mathrm{H}-\mathrm{O}$ soil, it declined over seven days to about $100 \mathrm{mg} \mathrm{kg}^{-1}$ at the end of the experiment, i.e., almost to the level of control soils.

Under variable conditions, MB-C did not vary significantly during the first four weeks of incubation, in neither $\mathrm{L}-\mathrm{V}$ nor $\mathrm{H}-\mathrm{V}$, compared with the respective controls. In the following weeks, MB-C tended to decrease in L-V and to increase slightly in $\mathrm{H}-\mathrm{V}$ but, at the end of the experiment, MB-C contents in both samples were low $\left(\sim 100 \mathrm{mg} \mathrm{kg}^{-1}\right)$, not significantly different from the controls.

Soil basal respiration (SBR), i.e., the amount of organic carbon mineralized by soil microorganisms, is shown in figure 2. In all cases, respiration was lower in $\mathrm{H}$ than in $\mathrm{L}$ soil at the same moisture levels. In low-tillage soil (L), basal respiration was significantly related to moisture and higher than in the respective controls: SBR was higher in L-60 than in the other two soils and 3-fold higher than in the control; while in L-20 and in L-40 it was twice as high, showing that pellet application caused an increase in basal respiration proportional to soil moisture, while in the control samples, mineralization 
remained at the same level when WHC increased from 40 to $60 \%$. Many authors have reported that, under good nutritional conditions, soil basal respiration varies considerably with variations in soil moisture after rain events (Miller at al., 2005; Sponseller, 2007; Misson et al., 2010).

In $\mathrm{H}$ samples, soil basal respiration had a different pattern and was five times higher in treated than in untreated samples, independently of the soil moisture content. In the control samples, SBR was very low due to a deficiency of C-substrate and tended to increase in response to pellet application, but was not influenced by moisture.

Since nutrient release from organic amendment is mainly mediated by soil biochemical activity, it is important to investigate how soil enzymes respond to pellet application. Pellet application slightly influenced the investigated enzyme activities; thus, only the mean values referred to the entire period (Figure 3). Hydrolytic activities, determined by the $\beta$-GLU activity, appeared to be more affected by soil moisture content than by
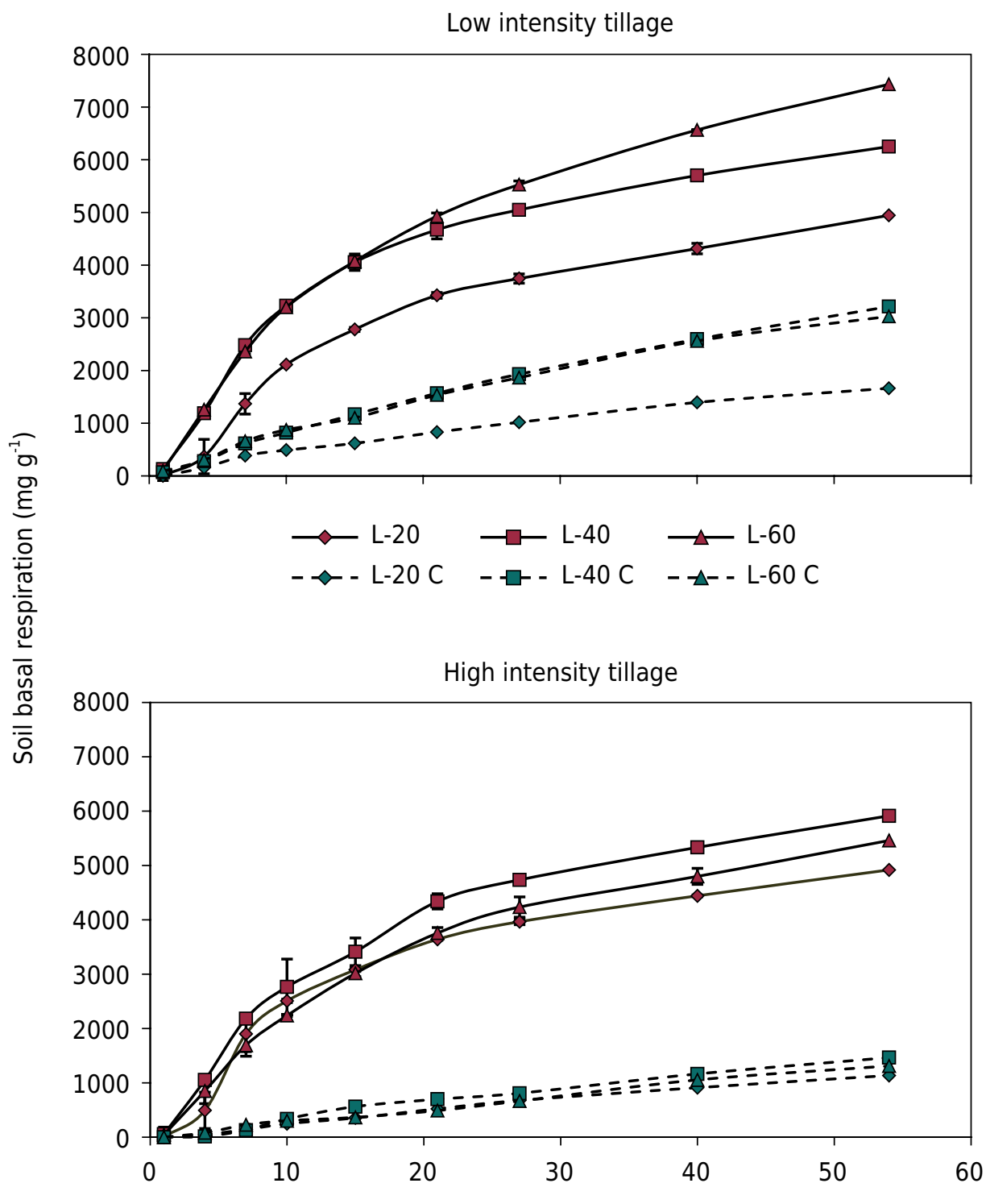

Days after treatment

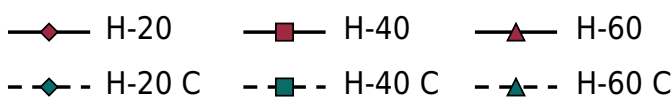

Figure 2. Soil basal respiration (SBR) in untreated (C) and treated soils under low tillage intensity $(\mathrm{L})$ and high tillage intensity $(\mathrm{H})$, at different soil moisture conditions $(20,40$ and $60 \% \mathrm{WHC}$. 
the presence of pellet. A higher increase was found for L-O, which increased by $84.2 \%$ in L-V. At the same time, no significant differences were observed between treated and untreated samples. The only exception was L-O, where $\beta$-glucosidase increased by about $25 \%$ compared to the respective control. Similarly, alkaline phosphatase was found to significantly increase only in response to soil moisture and not to pellet application. These two enzymatic activities were higher in $\mathrm{L}$ than in $\mathrm{H}$ soil, evidencing a higher soil fertility level at low tillage intensity. Differently, o-diphenoloxidase was not significantly influenced by soil moisture, neither by pellet application, but was markedly higher in $\mathrm{H}$ than $\mathrm{L}$ soil. As the o-DPO activity is a good index to estimate soil organic carbon humification, a faster humification of soil organic matter in soil under high tillage intensity would be hypothesized.
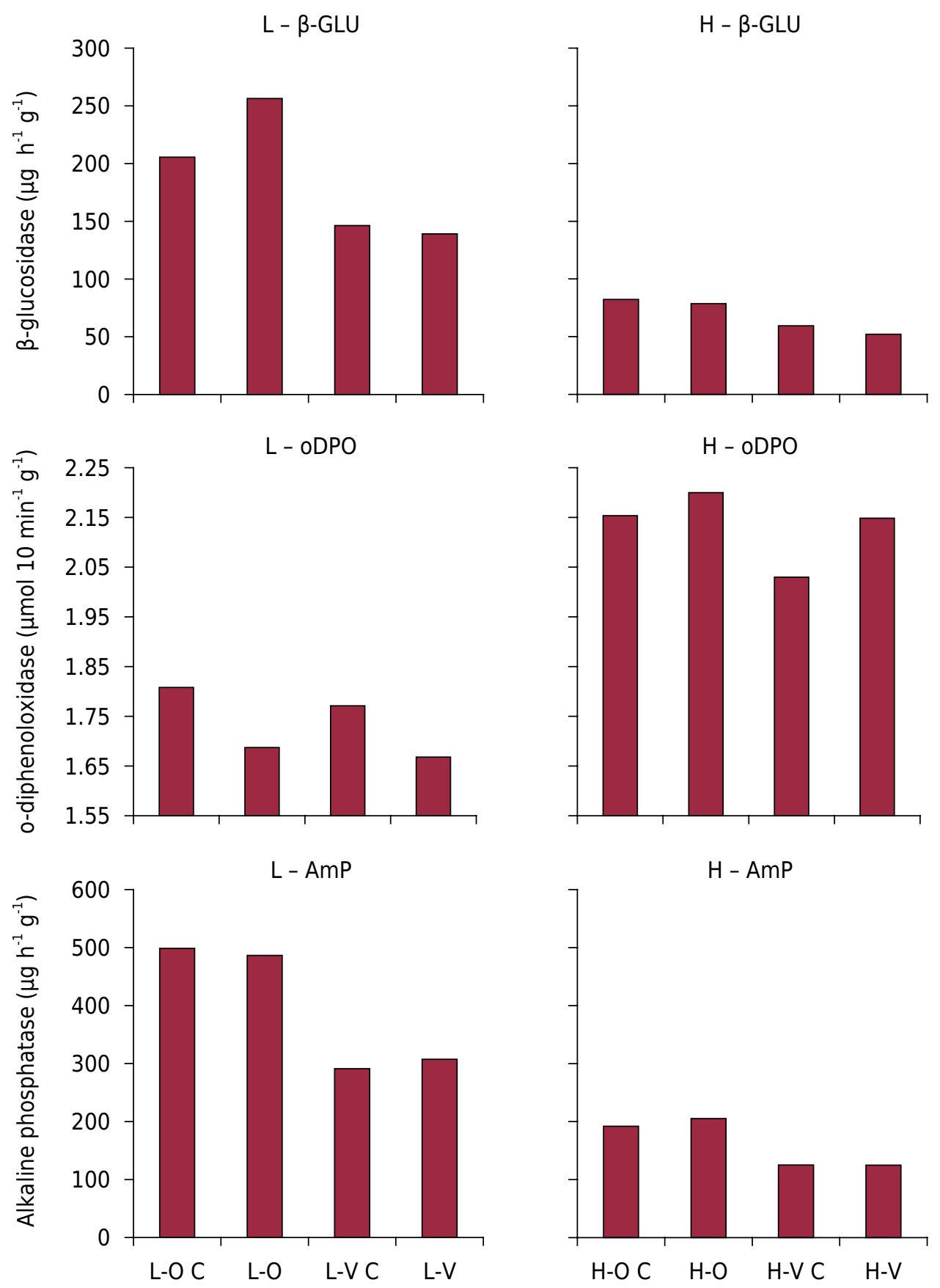

Figure 3. $\beta$-glucosidase, o-diphenoloxidase, alkaline phosphatase in un-treated (C) and treated soils under low tillage intensity $(\mathrm{L})$ and high tillage intensity $(\mathrm{H})$, at optimal $(\mathrm{O})$ and variable $(\mathrm{V})$ temperature and soil moisture conditions, reported as mean values for the entire incubation period. 
L - Optimal conditions

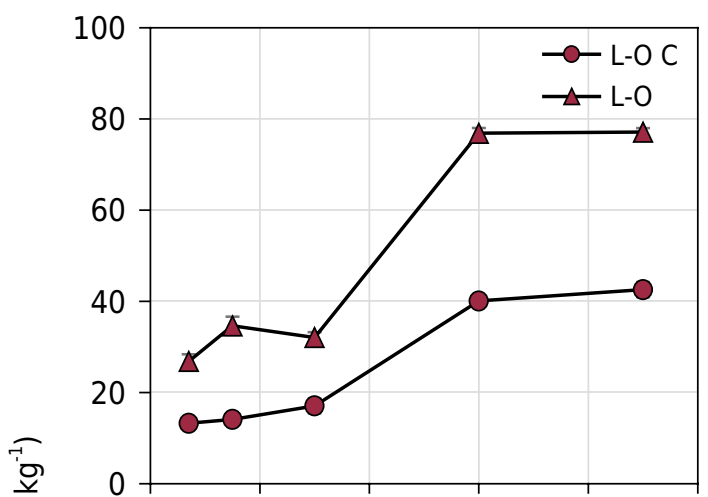

$\mathrm{L}$ - Variable conditions

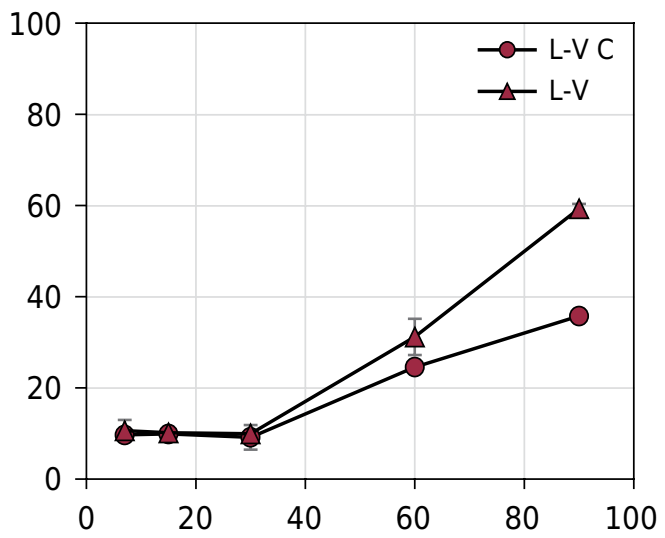

H - Optimal conditions

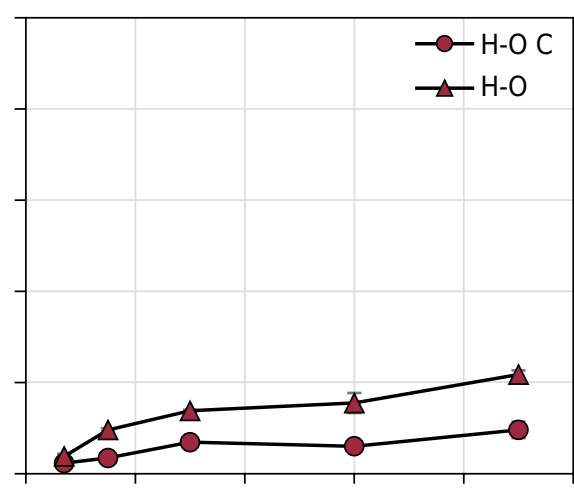

H - Variable conditions

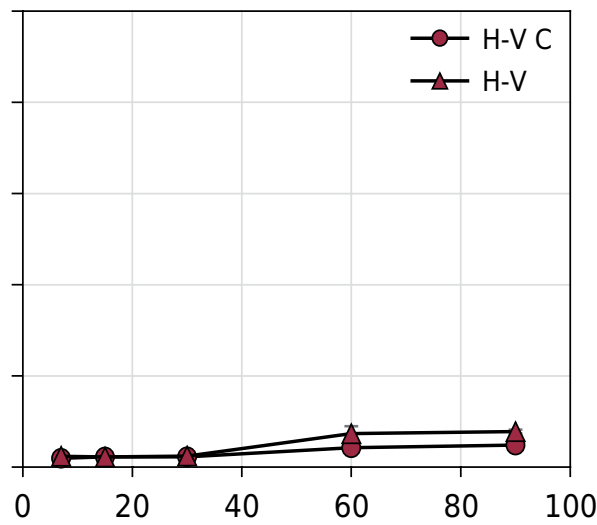

Days after treatment

Figure 4. Amount of $\mathrm{N}-\mathrm{NO}_{3}$ release in un-treated (C) and treated soils under low tillage intensity $(\mathrm{L})$ and high tillage intensity $(\mathrm{H})$, at optimal $(\mathrm{O})$ and variable $(\mathrm{V})$ temperature and soil moisture conditions (mean of four replicates \pm standard deviation).

Figure 4 shows the results of the amount of available $\mathrm{N}-\mathrm{NO}_{3}$ released from the treated soils during the 90 -day experiment. High tillage intensity soils were overall characterized by a lower $\mathrm{N}-\mathrm{NO}_{3}$ release than $\mathrm{L}$ soils, even if the release increased during the experiment in both soils until day 90 , when $\mathrm{N}^{-\mathrm{NO}_{3}}$ was $8.0 \mathrm{mg} \mathrm{kg}^{-1}$ in $\mathrm{H}-\mathrm{V}, 21.5 \mathrm{mg} \mathrm{kg}^{-1}$ in $\mathrm{H}-\mathrm{O}$, $56.0 \mathrm{mg} \mathrm{kg}^{-1}$ in L-V and $77.0 \mathrm{mg} \mathrm{kg}^{-1}$ in L-O, significantly different from the respective controls in all cases. Subtracting mineralized $\mathrm{N}^{-\mathrm{NO}_{3}}$ in the respective control soils, over a 90-day period, showed that under variable soil moisture conditions, 5.5 and $44.6 \%$ of organic $\mathrm{N}$ applied with pellet was mineralized in $\mathrm{H}-\mathrm{V}$ and $\mathrm{L}-\mathrm{V}$, respectively. On the other hand, under optimal soil conditions, $\mathrm{N}-\mathrm{NO}_{3}$ release represented 22.5 and $64.1 \%$ of the organic $\mathrm{N}$ applied in pellet to $\mathrm{H}-\mathrm{O}$ and $\mathrm{L}-\mathrm{O}$, respectively, in agreement with other reports. Under optimal moisture conditions (60\% WHC) and after 84 days of incubation, Lazicki et al. (2020) reported a N release range from pelletized poultry manure of 35-55 \%.

\section{DISCUSSION}

Various studies have related a high SOM content with the capacity of microorganisms to metabolize organic substrates (Bending et al., 2002; Santos et al., 2012). Many authors showed that soil microbial biomass content, activity and population abundance are positively affected by reduced or no-tillage practices (Meriles et al., 2009; Jangid et al., 2011; Mbuthia et al., 2015), indicating a positive effect of reduced tillage intensity on soil quality (Ashworth et al., 2017). Crop residue management can also have a positive impact on key soil functions. In particular, the retention of crop residues on the soil surface after harvest, coupled with no-tillage practices, increases the microbial biomass 
level and diversity, as confirmed by other authors (Govaerts et al., 2008; Helgason et al., 2009; Navarro-Noya et al., 2013; Monaci et al., 2017). Crop rotations also increase microbial diversity, possibly improving key soil functions, since plant species tend to select distinct microbial populations via rhizodeposition and litter shedding (Alvey et al., 2003; Zhang et al., 2014).

Under optimal conditions, MB-C content increased relatively more in $\mathrm{H}-\mathrm{O}$ than $\mathrm{L}-\mathrm{O}$ soil in the first seven days of incubation (Figure 1), due to the very low initial amount of organic carbon in $\mathrm{H}-\mathrm{O}$ soil. Possibly, soil microorganisms were more benefitted by the higher amount of organic carbon added with the pellet, but the relatively low initial fertility level did not sustain a further increase in MB-C, which decreased more rapidly than in L-O soil.

This performance could be explained by the soil moisture content which may have been a limiting factor during the first two weeks of incubation. Indeed, a $15 \%$ soil moisture content may have been insufficient to fully re-hydrate the pellet, allowing only a partial use as a $C$ source. Microbial biomass could benefit most from pellet application between the 2nd and 6th week of incubation, when moisture increased in both soils. In general, soil microbial activity increases with increasing soil moisture (Or et al., 2007; Borowik and Wiszkowska, 2016), and the soil drying-rewetting stress could cause changes in microbial biomass growth and activity (Pesaro et al., 2004; Schimel et al., 2007). The MB-C results in this experiment are in line with the above affirmation: soil microbial biomass increases at optimal soil moisture, while under moisture stress, the bioavailability of nutrients for microbial biomass is limited and growth and microbial biomass activity are reduced (Or et al., 2007; Siebielec et al., 2020). The variable soil moisture conditions tested in this experiment simulated those of Mediterranean climatic conditions, where numerous drying/rewetting cycles succeed each other, which could strongly influence microbial biomass structure and activity (Miller et al., 2005; Misson et al., 2010). However, the tested variable conditions were not favorable for microbial biomass growth, and, at the end of the experiment, MBC decreased to levels not significantly different from the controls.

With regard to SBR (Figure 2), it can be deduced that, in the case of $L$ soils, with a higher fertility level, soil moisture limited basal respiration. In $\mathrm{H}$ soils however, the limiting factor was low fertility, so that respiration increased when pellet was applied, supplying the $C$ source for microbial biomass.

As all investigated enzymatic activities in treated soils varied little compared to the untreated control (Figure 3), we suggest that pellet application contributes only slightly to improving soil biochemical fertility. In a laboratory study on the influence of soil moisture and chemical properties on seven enzymatic activities, including those assessed in this experiment, Borowik and Wiszkowska (2016) found that the influence of soil moisture on biochemical activity was far smaller than that of properties such as organic carbon and $\mathrm{pH}$, confirming our results.

The efficiency of nutrient release from pelletizing organic amendment may vary greatly and be affected by soil moisture as well as the microbial biomass level and activity (Agehara and Warncke, 2005; Borowik and Wiszkowska, 2016). In this experiment, results showed that, under variable conditions, namely at 30 and $20 \% \mathrm{WHC}$ in $\mathrm{H}$ and $\mathrm{L}$ soil, the pellet was so durable that microorganisms could not use it entirely as carbon source for growth during the first 21-30 days after application (Figure 4). This implies that the pellet may remain undecomposed and underused in arable soils. Consequently, in dry periods, nutrient release could be strongly reduced in the absence of irrigation.

Another important factor that regulates the fertilizing efficiency of pelletized poultry litter amendment is the microbial biomass level and activity of the native soil. Organic substrates can change the decomposition rate of soil organic matter, termed as "priming effect" (Li et al., 2018; Zhang et al., 2019; Feng et al., 2021). This effect is 
often caused by an overall increase in microbial activity due to a higher availability of energy resulting from the decomposition of fresh organic matter.

Under optimal soil moisture conditions (60\% WHC), microbial mineralization and $\mathrm{N}-\mathrm{NO}_{3}$ release varied markedly between the two investigated soil treatments. If soil microorganisms in $\mathrm{H}$ could benefit more from pellet application than those in $\mathrm{L}$ soil, on the other hand, their content and/or activity did not allow a release of more than $22.5 \%$ of the total organic $\mathrm{N}$ applied with pellet, compared to the $64.5 \%$ released from microbial mineralization in $\mathrm{L}$ soil.

Possibly, the priming effect resulted from the competition for energy and nutrient acquisition between the decomposer microorganisms specialized in fresh organic matter and those in soil organic matter (Fontaine et al., 2003). Gaudel et al. (2021) reported that the priming effect on native soil organic matter induced by exogenous glucose was more pronounced in the deeper soil layer with a lower native content of organic matter than that in the surface layer; the authors also observed a negative correlation of the priming effect with microbial biomass carbon and soil organic carbon. However, the duration of this experiment was relatively short and results could change if the priming effect were studied on an annual scale, since a first phase of negative influence of exogenous addition of organic carbon (first 90 days) might be followed by a positive pulse (Zhang et al., 2017).

\section{CONCLUSIONS}

The influence of soil management system, moisture conditions and chemical and biochemical properties on the efficiency of $\mathrm{N}-\mathrm{NO}_{3}$ release from pelletized organic poultry litter amendment was investigated. Our results show that soil moisture content and management system can have restrictive effects on $\mathrm{N}-\mathrm{NO}_{3}$ release from pelletized poultry fertilizer and also affect soil microbial biomass. A priming effect seems to occur when pellet is applied to soil, resulting in an intensified use of organic carbon of pellet in soil under high-intensity tillage and optimal moisture and temperature conditions.

\section{AUTHOR CONTRIBUTIONS}

Conceptualization: Carlo Angeletti (equal), (D) Costantino Vischetti (equal) and (D) Elga Monaci (equal).

Data curation: Carlo Angeletti (equal), (D) Costantino Vischetti (equal), (D) Cristiano Casucci (equal) and (D) Elga Monaci (equal).

Formal analysis: (D) Cristiano Casucci (equal) and (D) Elga Monaci (equal).

Funding acquisition: (DD Costantino Vischetti (lead).

Investigation: Carlo Angeletti (equal), (D) Costantino Vischetti (equal), (D) Cristiano Casucci (equal) and (D) Elga Monaci (equal).

Methodology: (D) Cristiano Casucci (equal), (D) Costantino Vischetti (equal) and (D) Elga Monaci (lead).

Resources: (iD Costantino Vischetti (lead).

Supervision: (D) Costantino Vischetti (lead).

Validation: Carlo Angeletti (equal), (D) Cristiano Casucci (equal) and (D) Elga Monaci (equal).

Writing - original draft: (D) Elga Monaci (equal) and (DD Costantino Vischetti (equal). 


\section{REFERENCES}

Agehara S, Warncke DD. Soil moisture and temperature effects on nitrogen release from organic nitrogen sources. Soil Sci Soc Am J. 2005;69:1844-55. https://doi.org/10.2136/sssaj2004.0361

Alvey S, Yang C-H, Buerkert A, Crowley DE. Cereal/legume rotation effects on rhizosphere bacterial community structure in West African soils. Biol Fertil Soils. 2003;37:73-82. https://doi.org/10.1007/s00374-002-0573-2

Ashworth AJ, DeBruyn JM, Allen FL, Radosevich M, Owen P. Microbial community structure is affected by cropping sequences and poultry litter under long-term no-tillage. Soil Biol Biochem. 2017;114:210-9. https://doi.org/10.1016/j.soilbio.2017.07.019

Bending GD, Turner MK, Jones JE. Interactions between crop residue and soil organic matter quality and the functional diversity of soil microbial communities. Soil Biol Biochem. 2002;34:1073-82. https://doi.org/10.1016/S0038-0717(02)00040-8

Borowik A, Wyszkowska J. Soil moisture as a factor affecting the microbiological and biochemical activity of soil. Plant Soil Environ. 2016;62:250-5. https://doi.org/10.17221/158/2016-PSE

Drozdz D, Wystalska K, Malinska K, Grosser A, Grobelak A, Kacprzak M. Management of poultry manure in Poland - Current state and future perspectives. J Environ Manag. 2020;264:110327. https://doi.org/10.1016/j.jenvman.2020.110327

Dumontet S, Mathur SP. Evaluation of respiration-based methods for measuring microbial biomass in metal-contaminated acidic mineral and organic soils. Soil Biol Biochem. 1989;21:431-6. https://doi.org/10.1016/0038-0717(89)90155-7

Eivazi F, Tabatabai MA. Glucosidases and galactosidases in soils. Soil Biol Biochem. 1988;20:601-6. https://doi.org/10.1016/0038-0717(88)90141-1

Eivazi F, Tabatabai MA. Phosphatases in soils. Soil Biol Biochem. 1977;9:167-77. https://doi.org/10.1016/0038-0717(77)90070-0

Feng J, Tang M, Zhu B. Soil priming effect and its responses to nutrient addition along a tropical forest elevation gradient. Glob Change Biol. 2021;27:2793-806. https://doi.org/10.1111/gcb.15587

Fontaine S, Mariotti A, Abbadie L. The priming effect of organic matter: a question of microbial competition? Soil Biol Biochem. 2003;35:837-43. https://doi.org/10.1016/S0038-0717(03)00123-8

Gaudel G, Poudel M, Mosongo PS, Xing L, Oljira AM, Zhang Y, Bizimana F, Liu B, Wang $Y$, Dong W, Uwamungu JY, Hu C. Meta-analysis of the priming effect on native soil organic carbon in response to glucose amendment across soil depths. Plant Soil. 2021. https://doi.org/10.1007/s11104-021-05168-5

Govaerts B, Mezzalama M, Sayre KD, Crossa J, Lichter K, Troch V, Vanherck K, De Corte P, Deckers J. Long-term consequences of tillage, residue management, and crop rotation on selected soil micro-flora groups in the subtropical highlands. Appl Soil Ecol. 2008;38:197-210. https://doi.org/10.1016/j.apsoil.2007.10.009

Helgason BL, Walley FL, Germida JJ. Fungal and bacterial abundance in long-term, no-till and intensive-till soils of Northern Great Plains. Soil Sci Soc Am J. 2009;73:120-7. https://doi.org/10.2136/sssaj2007.0392

Jangid K, Williams MA, Franzluebbers AJ, Schmidt TA, Coleman DC, Whitman WB. Land-use history has a stronger impact on soil microbial community composition than aboveground vegetation and soil properties. Soil Biol Biochem. 2011;43:2184-93. https://doi.org/10.1016/j.soilbio.2011.06.022

Lazicki P, Geissler D, Lloyd M. Nitrogen mineralization from organic amendments is variable but predictable. J Environ Qual. 2020;49:483-95. https://doi.org/10.1002/jeq2.20030

Li L-J, Zhu-Barkerb X, Ye R, Doane TA, Horwath WR. Soil microbial biomass size and soil carbon influence the priming effect from carbon inputs depending on nitrogen availability. Soil Biol Biochem. 2018;119:41-9. https://doi.org/10.1016/j.soilbio.2018.01.003

Lopez-Mosquera ME, Cabaleiro F, Sainz MJ, Lopez-Fabal A, Carral E. Fertilizing value of broiler litter: Effects of drying and pelletizing. Biores Technol. 2008;99:5626-33. https://doi.org/10.1016/j.biortech.2007.10.034 
Loyon L. Overwiew of manure treatment in France. Waste Manag. 2017;61:516-20. https://doi.org/10.1016/j.wasman.2016.11.040

Mbuthia L, Acosta-Martinez V, Debryun J, Shaeffer SM. Long term tillage, cover crop, and fertilization effect on microbial community structure, activity: Implication for soil quality. Soil Biol Biochem. 2015;89:24-34. https://doi.org/10.1016/j.soilbio.2015.06.016

McMullen J, Fasina OO, Wood CV, Feng Y. Storage and handling characteristics of pellets from poultry litter. Appl Eng Agric. 2008;21:645-51. https://doi.org/10.13031/2013.18553

Meriles JM, Vargas SG, Conforto C, Figoni G, Lovera E, March GJ, Guzman, CA. Soil microbial communities under different soybean cropping systems: characterization of microbial population dynamics, soil microbial activity, microbial biomass, and fatty acid profiles. Soil Till Res. 2009;103:271-81. https://doi.org/10.1016/j.still.2008.10.008

Miller AE, Schimel JP, Meixner T, Sickman JO, Melack JM. Episodic rewetting enhances carbon and nitrogen release from chaparral soils. Soil Biol Biochem. 2005;37:2195-204. https://doi.org/10.1016/j.soilbio.2005.03.021

Ministero delle Politiche Agricole Alimentari e Forestali - Mipaaf. Italian Ministry of Agriculture, Alimentary and Forestry Policy Circular N.9594661 of 10/10/95; 1995. [cited 2021 Jan 31]. Available from: https://www.sinab.it/normativa/circolare-ministeriale-n-9594661-del-10101995.v.

Misson L, Rocheteau A, Rambal S, Ourcival J-M, Limousin J-M, Rodriguez R. Functional changes in the control of carbon fluxes after 3 years of increased drought in a Mediterranean evergreen forest? Glob Change Biol. 2010;16:2461-75. https://doi.org/10.1111/j.1365-2486.2009.02121.x

Monaci E, Polverigiani S, Neri D, Bianchelli M, Santilocchi R, Toderi M, D'Ottavio P, Vischetti $C$. Effect of contrasting crop rotation systems on soil chemical and biochemical properties and plant root development in organic farming: first results. Ital J Agron. 2017;12:364-74. https://doi.org/10.4081/ija.2017.831

Navarro-Noya Y, Gomez-Acata S, Montoya-Ciriaco N, Rojas-Valdez A, Suoarez-Arriaga MC, Valenzuela-Encinas C, Jimenez-Bueno N, Verhulst N, Govaerts B, Dendoven L. Relative impact of tillage, residue management and crop rotation on soil bacterial communities in a semi-arid agroecosystem. Soil Biol Biochem. 2013;65:86-95. https://doi.org/10.1016/j.soilbio.2013.05.009

Or D, Phutane S, Dechesne A. Extracellular polymeric substances affecting pore-scale hydrologic conditions for bacterial activity in unsaturated soils. Vadose Zone J. 2007;6:298-305. https://doi.org/10.2136/vzj2006.0080

Paetz A, Wilke BM. Soil sampling and storage. In: Margesin R, Schinner F, editors. Soil biology, manual for soil analysis. Berlin: Springer-Verlag; 2005. p. 1-45. https://doi.org/10.1007/3-540-28904-6_1

Paul EA, Clark FE. Soil microbiology and biochemistry. San Diego: Academic Press; 1996.

Perucci $P$, Casucci C, Dumontet S. An improved method to evaluate in situ the o-diphenoloxidase activity of soil. Soil Biol Biochem. 2000;32:1927-33. https://doi.org/10.1016/S0038-0717(00)00168-1

Pesaro M, Nicollier G, Zeyer J, Widmer F. Impact of soil drying-rewetting stress on microbial communities and activities and on degradation of two crop protection products. Appl Environ Microbiol. 2004;70:2577-87. https://doi.org/10.1128/AEM.70.5.2577-2587.2004

Santos VB, Araújo ASF, Leite LFC, Nunes LAPL, Melo WJ. Soil microbial biomass and organic matter fractions during transition from conventional to organic farming systems. Geoderma. 2012;170:227-31. https://doi.org/10.1016/j.geoderma.2011.11.007

Schimel J, Balser TC, Wallenstein M. Microbial stress-response physiology and its implications for ecosystem functioning. Ecology. 2007;88:1386-94. https://doi.org/10.1890/06-0219

Siebielec S, Siebielec G, Klimkowicz-Pawlas A, Gałazka A, Grzadziel J, Stuczynski T. Impact of water stress on microbial community and activity in sandy and loamy soils. Agronomy. 2020;10:1429. https://doi.org/10.3390/agronomy10091429

Sims JT, Wolf DC. Poultry waste management: Agricultural and environmental issues. Adv Agron. 1994;52:1-83. https://doi.org/10.1016/S0065-2113(08)60621-5 
Soil Survey Staff. Keys to soil taxonomy. 12th ed. Washington, DC: United States Department of Agriculture, Natural Resources Conservation Service; 2014.

Sponseller RA. Precipitation pulses and soil $\mathrm{CO}_{2}$ flux in a Sonoran Desert ecosystem. Glob Change Biol. 2007;13:426-36. https://doi.org/10.1111/j.1365-2486.2006.01307.x

Vance ED, Brookes PC, Jenkinson DS. An extraction method for measuring soil microbial biomass-C. Soil Biol Biochem. 1987;19:703-7. https://doi.org/10.1016/0038-0717(87)90052-6

Zhang B, Li Y, Ren T, Tian Z, Wang G, He X, Tian C. Short-term effect of tillage and crop rotation on microbial community structure and enzyme activities of a clay loam soil. Biol Fertil Soils. 2014;50:1077-85. https://doi.org/10.1007/s00374-014-0929-4

Zhang X, Han X, Yu W, Wang P, Cheng W. Priming effects on labile and stable soil organic carbon decomposition: Pulse dynamics over two years. PLoS ONE. 2017;12:e0184978. https://doi.org/10.1371/journal.pone.0184978

Zhang Z, Wang W, Qi J, Zhang H, Tao F, Zhang R. Priming effects of soil organic matter decomposition with addition of different carbon substrates. J Soils Sediments. 2019;19:1171-8. https://doi.org/10.1007/s11368-018-2103-3 